\title{
Lactic Acid Profile of Bali cattle during Rest Period Before Slaughtered
}

\author{
Siswanto $^{1}$, I Nyoman Sulabda ${ }^{2}$ \\ ${ }^{1}$ Veterinary Physiology Laboratory, Department of Veterinary Medicine Faculty of \\ Veterinary Medicine, Udayana University, Bali, Indonesia \\ Email : siswanto@unud.ac.id \\ ${ }^{2}$ Veterinary Physiology Laboratory, Department of Veterinary Medicine Faculty of \\ Veterinary Medicine, Udayana University, Bali, Indonesia, \\ Email : n.sulabda@unud.ac.id
}

Corresponding author: siswanto@unud.ac.id

\begin{abstract}
The animal products quality is influenced the physiological compounds in the blood, for example lactic acid. If blood lactic acid levels increase before slaughtering will be accelerate the rigor mortis of meat, thus faster handling is needed. Blood lactic acid also affects the appearance of flesh color of meat. The condition of animals before slaughter (rest period in quarantine) is very influential on rigor mortis. It is important to research blood lactic acid levels before animals are slaughtered. This research was conducted to determine the blood lactic acid levels of bali cattle during the rest period before the animal was slaughtered (ante mortem), so it can be predicted the quality of meat products. Purposive was chosen as a sampling method using elisa test as a determination of lactic acid levels. Fourtysamples of blood taken from cows to be slaughtered at Sanggaran Animal Abattoir, Denpasar, Bali. The results showed that the blood levels of lactic acid in cattle would be cut normally. This shows the quality of resting cattle before slaughter is good.
\end{abstract}

Keywords: lactic acid, blood, cattle.

\section{INTRODUCTION}

Cattle are one of the potential meat-producing animals or livestock and are widely consumed by the Balinese, including throughout Indonesia. Most people consume beef in urban areas, this is motivated by the establishment from an economic perspective. On the other hand, the centers producing cattle from the farmers are mostly in the village. Meanwhile the location of abattoirs is also in urban areas which are usually quite far away. Problems arise in terms of sending livestock to slaughterhouses and animal breaks. Shipping animals from production centers to slaughterhouses requires land and even sea transportation, so that animals often suffer from stress and stress. This results in decreased appetite, which in turn can reduce the weight of cattle and it is not uncommon for animals to become sick. Therefore, comfort and welfare of animals during transportation must receive attention, because this is very influential on health which in turn will affect the quality of meat products. Another factor 
influencing the quality of meat is the poor rest period before livestock is slaughtered. Poor periods of rest cause lactic acid levels to increase. High blood lactic acid before slaughtering will speed up the stiffness (rigor mortis) of animals after slaughtering, thus requiring faster processing. Blood lactic acid also influences the appearance of flesh color, thereby reducing the appearance and taste of meat.

Meat from large animals such as cows, buffaloes, pigs are generally red and classified as red meat, while meat from small animals such as chicken, ducks and other poultry is called white meat. The color of the meat depends on the meat fibers that make it up, if the meat is composed of many red fibers classified as red meat and vice versa meat contains more white fiber classified as white meat [1]

Related to the supply of meat products, the life phase of being a carcass is a very risky phase, because this phase is strongly influenced by the condition of the animal before slaughtering, such as animal hygiene, health and sanitation, especially the physiological state of the animal. The physiological state is influenced by the type of feed given, the feasibility of transportation and rest time before the animal is slaughtered [2][3]. Hygienic meat production must begin with disease prevention during the maintenance and fattening of animals to be slaughtered, because animals are a source of diseases such as anthrac germs, mouth and nails, salmonella, coli and others. Transporting animals to abattoirs via land, sea or air transportation can cause stress and fatigue. So that it can cause psychological and physical disorders, such as stress and injury. This situation will result in decreased quality and sanitary meat. Slaughterhouse / cage as a place to rest animals before slaughter is a factor that determines the quality of meat. Therefore, it is necessary to be clean, quiet and comfortable and regularly cleaned and disinfected.

The slaughtering process is an important stage in the supply of meat, because the slaughtering procedure is a sequential technique that can affect changes in livestock / animals. The results of several studies indicate that there is a direct relationship between transportation time and carcass damage or poor quality meat. Factors affecting the quality of the carcass such as ambient temperature are too hot or too cold, rough treatment, noise that disturbs during transportation. Because it affects the physical condition of animals and causes stress in animal [4][5].

Poor and stressed animals have higher blood lactic acid levels. In conditions of exhaustion, animals 
experience energy deficiency, as a result the body oxidizes fat deposits. Under anaerobic conditions, oxidation in cells converts pyruvate to lactate and low energy production (ATP) [6]. Plasma lactate levels can be used as indicators of anaerobic metabolism and lack of oxygen. When oxygen is available again (by giving a good ration), most of the lactate will quickly be converted into pyruvate and then enter the Krebs cycle. Most of these changes occur in the heart [7] Lactic acid will speed up the process of rigor mortis, and rigor mortis will reduce the quality of meat. Increased lactic acid also has an impact on decreasing the $\mathrm{pH}$ of meat quickly. Low $\mathrm{pH}$ of meat will cause a decrease in water binding power (DMA), so it affects the level of meat elasticity [8][9]

Rigor mortis is an irreversible muscle stiffness, occurring after slaughter after primary relaxation. As the supravital reaction disappears, rigor mortis appears simultaneously on all voluntary and involuntary muscles. Rigor mortis in skeletal muscle actually occurs simultaneously in all muscles, but it is usually more real and easily observed in small muscles. The biochemical processes that take place before and after cattle are slaughtered until the formation of rigor mortis are generally a major phase of their role in meat quality. Error handling after slaughter to the rigor mortis phase can result in low quality meat characterized by dark firm dry or pale soft exudative or cold shortening or rigor formed after thawing frozen meat (thaw rigor) [10][11].

Excess carbohydrates from food consumed will be converted to glycogen and stored in the liver and muscles. Furthermore, this glycogen will be remodeled into lactic acid (anaerobic) or pyruvic acid (aerobic) to produce ATP (adenosine tri phosphate). ATP is used for the process of muscle contraction and relaxation. Shortly after the livestock dies, the remnants of glycogen and especially ATP formed before the livestock dies will still be used for muscle contraction until the ATP runs out. The result will be formed rigor mortis characterized by muscle stiffness. The production of ATP from glycogen through three channels namely the glycolysis pathway (reforming glycogen to lactic acid or pyruvic acid. Adenosine tri-phosphate (ATP) will be used as an energy source for contraction, pumping $\mathrm{Ca} 2$ ions during relaxation, and regulating the balance of $\mathrm{Na}$ and $\mathrm{K}$. The slow time needed for the formation of rigor mortis is highly dependent on the amount of ATP available at the time the livestock are slaughtered, and conditions that are less resting before slaughter and especially under conditions of stress or 
fatigue will accelerate the formation of rigor mortis [12].

Before rigor mortis occurs, the prarigor phase begins, the muscles contract and the muscle stiffness end. The time needed to form rigor mortis depends on the amount of ATP available at the time the livestock dies. The amount of ATP available is related to the amount of glycogen that is available just before the cattle die. In cattle that experience fatigue or stress and lack of rest before slaughter will result in a lack of ATP supply, so the rigor mortis process takes place quickly. Similarly, high temperatures when cattle are slaughtered will accelerate ATP out, due to an overhaul by the ATPase enzyme, so rogor mortis will take place quickly [9].

Rigor mortis occurs in a short time, resulting in the $\mathrm{pH}$ of the meat is still high (above the normal $\mathrm{pH}$ ). If the $\mathrm{pH}>5.5$ 5.8 during rigor mortis with a fast time from normal conditions, the quality of the meat to be produced will be low (dark red, dry and the structure is tight) and does not last long in storage even in cold temperatures. In the rigor mortis phase, the process of glycolysis will stop and ATP production decreases, resulting in anaerobic glycolysis which produces lactic acid. As a result of the reduced ATP, the distance between actin and myosin is getting closer, eventually it will coalesce to form actoniosin. This situation allows for more contractions and stiffness of the meat. The next phase is the post rigor phase, in this phase the meat is contaminated with microbes, as a result the meat becomes soft due to the role of the enzyme katepsin as the breakdown of actomyosin proteins into simple proteins [13].

\section{MATERIALS AND METHODS}

Samples (bali cow blood) were taken from the Abattoir, Sanggaran, Denpasar, Bali. The study was conducted in June 2019. The study used 40 samples of Balinese cow blood. Blood is drawn from cows that are resting in the Denpasar Sanggar Abattoir, using a $3 \mathrm{ml}$ syringe. Then the blood is transferred into a blood collecting tube with EDTA risk, put it in a cooling box.

Determination of lactic acid levels using the Enzyme-linked Immunosorbent Assay (Elisa) method.

Data were analyzed descriptively, which is described based on levels of lactic acid in blood plasma, then tabulated and described in a graph (chart).]

\section{RESULTS AND DISCUSSION}

\section{Results}

The results showed an average of $9.78 \pm$ $0.52 \mathrm{mg} / \mathrm{dL}$, more fully the data are presented in Table 1. 
Table 1. Test results for the Elisa Lactic Acid Levels in Bali cattle blood

\begin{tabular}{cccc}
\hline No Sample & $\begin{array}{c}\text { Lactic Acid Levels } \\
(\mathrm{mg} / \mathrm{dL})\end{array}$ & No Sample & $\begin{array}{c}\text { Lactic Acid Levels } \\
(\mathrm{mg} / \mathrm{dL})\end{array}$ \\
\hline 1 & 9.30 & 21 & 9.35 \\
2 & 9.50 & 22 & 9.55 \\
3 & 9.10 & 23 & 9.4 \\
4 & 10.1 & 24 & 10.1 \\
5 & 10.2 & 25 & 10.5 \\
6 & 9.25 & 26 & 9.5 \\
7 & 9.75 & 27 & 9.7 \\
8 & 9.8 & 28 & 9.8 \\
9 & 10.25 & 29 & 10.2 \\
10 & 11.2 & 30 & 10.2 \\
11 & 8.95 & 31 & 8.95 \\
12 & 9.25 & 32 & 9.25 \\
13 & 9.75 & 33 & 9.5 \\
14 & 9.2 & 34 & 9.25 \\
15 & 10.2 & 35 & 10.3 \\
16 & 10.5 & 36 & 10.6 \\
17 & 10.2 & 37 & 10.25 \\
18 & 9.3 & 38 & 9.35 \\
19 & 9.5 & 39 & 9.55 \\
20 & 10.2 & 40 & 10.25 \\
\hline Average & 9.77625 & & \\
\hline SD & 0.515387 & & \\
\hline & & & \\
\hline & & & \\
\hline
\end{tabular}

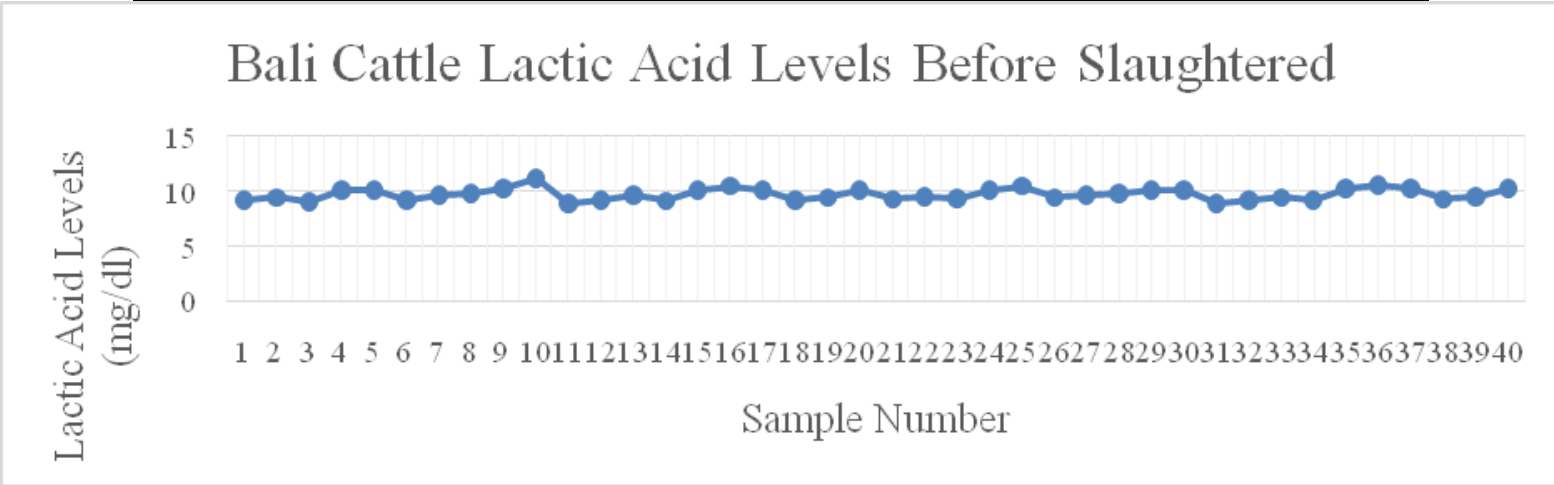

Figure 1. Graph of Lactic Acid Levels of Bali Cattle Before Slaughtered

\section{Discussion}

The average blood lactic acid level of Bali cattle is $9.78 \mathrm{mg} / \mathrm{dL}$ according to normal Bali cattle, this shows that the treatment during rest before the cattle is slaughtered is good. Even though the cattle were slaughtered before the process of transportation to the abattoir, the lactic acid picture showed normal. Handling during the break is done well and sufficient time, the feed is met, avoiding a tense environmental situation and comfortable conditions. The good rest period before animals are slaughtered, it can be predicted that the quality of meat will be good. 
As stated by Santosa et al., [14] that transportation involves several potential factors that can cause livestock to become stressed, including rough handling, mixing with unknown / foreign animals, different ages, lack of food and drink, comfort of transportation, number of animals transported, weather and humidity. Furthermore Grandin et al., [4] explained that animals that are not good in handling during transportation will become stressed. Stress can be observed by observing the clinical symptoms that appear. An animal that is stressed will be deficient in certain metabolites such as blood glucose, electrolytes and water, so that the animal will dehydrate. Severe glycogen deficiency often occurs in conditions of fatigue, hunger, fear and heat stress or aggressive behavior due to mixing with new strangers of cattle [15]. Stressed animals need recovery time, for example adequate rest, good feed / drink management. During the recovery the cows return to normal condition and eliminate the stress response [8][16].

Aradom [3] states that, lactate levels begin to increase when there is an energy requirement by the body's muscles as a result of increased stress. Oxygen deficiency causes lactic acid levels to increase, because oxygen deficiency causes anaerobic metabolism in the body, so glucose is converted to lactic acid.
Reduced glucose due to transportation stress results in an increase in the mobilization of muscle glycogen for the formation of energy through the process of glycolysis, thus causing low energy reserves (glycogen) found in the liver and muscles, ultimately increasing blood lactate levels.

The results of this study are similar to Anwar's [17] research although they use different methods. This shows that the level of lactic acid in Bali cattle is in the range of $9.8 \mathrm{ng} / \mathrm{dL}$ at rest.

\section{CONCLUSION}

It was concluded that the cattle slaughtered at the slaughterhouse of Sanggaran, Denpasar, Bali, Indonesia were good. This shows that handling during the rest / quarantine period before the cattle are slaughtered is good.

\section{ACNOWLEDGMENT}

Thank you to the LPPM parties who have funded this research through a work contract with the Work Agreement (SPK) number: 1222 / UN14.2.9 / LT / 2019. Thank you also the authors convey to the Veterinary Center Level I Denpasar, Bali for the facilities and infrastructure that have been provided so that the implementation of this research. 


\section{REFERENCES}

[1] Puolanne, EJ, Pösö AR, Ruusunen MH, Sepponen KV, KyläPuhjuMS. 2002. Lactic Acid in Muscle and its Effects on Meat Quality. Proceedings of the 55th Reciprocal Meat Conference. Department of Food Technology/Meat Technology University of Helsinki Viikki E, P.O. Box 27, FIN - 00014 Helsinki, Finland.

[2] Al-Haidary, AA. 2004. Physiological Responses of Naimey Sheep to Heat Stress Challenge under Semi-Arid Environments. International Journal of Agriculture \& Biology. Saudi arabia: Animal Production Department. College of AgricultureKing Saud University.

[3] Aradom, S. 2013. Animal Transport and Welfare with Special Emphasis on Transport Time and Vibration [Doctoral Thesis]. Uppsala: Swedish University of Agricultural Sciences.

[4] Grandin T. 2000. Livestock Handling and Transport. 2th edision. Departement of animal science, Colorado university. ISBN: 0-85199-409-1. USA: Cabi publishing.

[5] Gebresebet G, Sällvik K. 2006. Animal Welfare Aspects -the Technical Challenge During Housing, Transport and Slaughter: Dairy Cows. in: Geers R, Madec F, editor. Livestock Production and Society. Netherlands: Wageningen Academic Publishers.

[6] Koolman J, Röhm KH. (2005). Color atlas of biochemistry. Thieme Stuttgart.

[7] Botha SStC, Hoffman LC, Britz TJ. 2008. Effects of Post Mortem Temperature on Rigor Tension, Shortening and $\mathrm{pH}$ in Ostrich
Muscle. South African Journal of Animal Science 2008, 38 (3) p. 184.

[8] Borel EHV. 2001. The Biology of Stress and its Application to Livestock Housing and Transportation Assessment. Journal of Animal Science. American Society of Animal Science.

[9] de Castro PL, Lewandowski V, de Souza MLR, Coradini MF, Alexandre AAC, César Sary C, Ribeiro RP. 2017. Effect of Different Periods of Pre-Slaughter Stress on The Quality of The Nile Tilapia Meat. Food Sci. Technol (Campinas). Vol.37 no.1 Campinas Jan.

[10] Dewi SHC. 2012. Korelasi Antara Kadar Glikogen, AsamLaktat, $\mathrm{pH}$ Daging Dan SusutMasakDagingDomba Setelah Pengangkutan. 2012. JurnalAgriSains Vol. 4 No. 5.p. 59-70.

[11] ELkhasmi M, Chakir Y, Riad F, Safwate A, Tahri EH, Farh M, El Abbadi N, Abouhafs R, Faye B. 2013. Effect of Transportation Stress During the Hot-Season on some Haematological and Physiological Parameters in Moroccan Camels (Camelus Dromedarius). Journal of Life Sciences (Libertyville, USA), 7(1). p. 13-25.

[12] Savenije B, Lambooij E, Gerritzen MA, Venema K, Korf J. 2002. Effects of Feed Deprivation and Transport on Preslaughter Blood Metabolites, Early Postmortem Muscle Metabolites, and Meat Quality. Poult Sci. 2002 May;81(5):699-708.

[13] Broom DM. 2005. The Effect of Land Transport on Animal Welfare. Department of Veterinary Medicine. University of Cambridge. Madingley Road. 
Cambridge CB3 0ES.United Kingdom.

[14] Santosa U, Tanuwiria UH, Yulianti A, Suryadi U. (2012). Utilization of organic chromium from tannery waste on reducing transportation stress and shortening recovery period at beef cattle. Jurnal Ilmu Ternak dan Veteriner, 17(2), 132141.

[15] Kannan K, Jain SK. (2000). Oxidative stress and apoptosis. Pathophysiology,7 (3), 153-163.
[16] Ndlovu T, Chimonyo M, OkohAI, Muchenje V.2008. A comparison of stress hormone concentrations at slaughter in Nguni, Bonsmara and Angus steers. African Journal of Agricultural Research, 3(2), 096100.

[17] Anwar, NI. 2015. Status IstirahatTerhadapProfil Darah Sapi Bali SebelumPemotongan Di RPH Antang Makassar. Skripsi. Repository Hasanuddin University. Makassar, Indonesia. 